\title{
7
}

\section{Images and Imaginings of the Cold War - with a Focus on the Swiss View}

\author{
Markus Furrer
}

\section{Introduction}

When remembering the Cold War it would be unusual to think immediately of the complex historical period between 1947 and 1991 with all its political entanglements and interdependencies. Rather, ideas associated with this period tend to be images of the atomic mushroom cloud, James Bond-esque chases, the border fortifications of the Iron Curtain, the Kremlin in Moscow, the scowling expressions of Soviet heads of state, parades and victory marches, scenarios from the Vietnam War or from mass demonstrations against the new arms resolution. These visual worlds vary strongly depending on the social origin of the individual and the generation to which the individual belongs. One's own experience and knowledge acquired early on about the period overlap with impressions from items one has read, seen and/or heard at a later stage.

\footnotetext{
M. Furrer $(\bowtie)$

University of Teacher Education Lucerne, Lucerne, Lucerne, Switzerland e-mail: markus.furrer@phlu.ch 
The main argument of this chapter is that people think about the Cold War in terms of images, which vary according to the individual or collectives to which an individual belongs, as well as to age group. But as a politico-ideological, economic, technological, scientific and sociocultural conflict, which deeply marked the everyday lives of individuals and collectives (Stöver 2007, 309-313), this event especially encourages visual thinking. Some of the images associated with the Cold War are widespread, such as the image of the Berlin Wall, which holds a dual significance as a symbol of both the division of Germany in 1961 and its reunification in 1989. 'The Fall of the Wall' simultaneously evokes an image and serves to abbreviate the narrative. Indeed the term 'Cold War' as coined by American journalist Herbert Swope ${ }^{1}$ around 1947 implies in itself a lively pictorial imagining around a cold confrontation. The Cold War was a 'war of cultures', against the background of which entertainment was used as a weapon on both sides in West and East (Stöver 2007, 269). Contemporary media presented apocalyptic visions, which created historical imagery. The doomsday clock, for instance, suggesting a countdown, stood metaphorically for a world inches away from the abyss.

Images of history are widely used in textbooks. Here they appear as fundamental interpretations in the authors' texts as well as in the illustrations, conjuring up an imagined history in readers' minds. This approach is inspired by Walter Benjamin's philosophy of history, which has visual thinking at its core (Weigel 1997; Buchbinder 2002, 15, 75) and conceives of history as essentially reduced to a set of images (Benjamin 1980; Buchbinder 2002, 75-84). In this sense, history is always a construct, constituted in the present moment. For Benjamin, this means that we are loading a past devoid of meaning with the 'here and now' (Benjamin $1980,701)$. In other words, past and present intermingle in historical narration. As building blocks of history, images are removed from their original contexts and lent meaning and significance in and by the present. Accordingly, how images might be manipulated and, consequently, how 'true' or 'false' the interpretations we make based on them are is of less concern here than the loading of historical images with relevance in and knowledge from the present (Furrer 2004, 104).

This is examined and exemplified in this chapter using the example of Swiss history textbooks and their representations of the Cold War. The 
question arises as to how the conflict is portrayed in the post-Cold War phase, noting that Switzerland is a special case in this context, being a Western and neutral country in which anti-communism was rampant. The Cold War ultimately led to Swiss neutrality being accepted, sometimes even appreciated, in both East and West. Switzerland decided, with a certain reluctance, to abstain from arming itself with nuclear weapons and rather focus on civil defence. No other country in the world invested so much in the construction of bunkers or civil defence facilities. Historians speak of 'total defence in a threatened small state' (Tanner 1988, 59); indeed, during the Cold War decades, Swiss society was considered to be in a 'state of emergency' (Albrecht et al. 1988), which rendered the end of the conflict a dramatic event for the Swiss self-image. Within society itself, enemy concepts had to be questioned, and the neutral small state had to reorient itself in terms of foreign policy. This new point of departure also influenced the image of the Cold War as presented in textbooks.

This chapter will thus focus on such images in textbooks. History textbooks are particularly important sources since they convey an officially sanctioned version of history (depending on their country of origin) and thus evoke specific historical images in order to be accepted and recognised. Dominant interpretations of the past find their way either intentionally or unwittingly into textbooks. But their authors also seek to reproduce official historical images, derived from research and embedded in memory culture (Furrer 2016, 280). The textbooks analysed in this chapter are aimed mainly at the secondary levels I and II in Switzerland; they were all produced and published after the Cold War and therefore reflect on the period before 'the Fall of the Wall' from a position of hindsight.

Historical images, especially when deployed in history textbooks, often allow authors to make interpretations on a macroscale by pairing the written text with illustrations or photographs. The historical image underlying the narrative becomes clearer, particularly in school history textbooks, which provide an overview of the period (Furrer, 117). As, however, they do not become historical images until they are accepted in the mind of the reader, their contours can also only be grasped through an analysis of textbook narratives. Whereas historians and social scientists explain the line of thought their narratives follow through the introduction of different theories and well-formulated arguments, when considering historical imagery in textbooks we must accept that we are mostly dealing 
with abbreviations (Rüsen 2008, 19) or narrative reductions. Such reductions are highly symbolic and allow readers to imagine a kind of historical painting (Furrer 2013, 221).

In the first section of this chapter, I examine theoretical approaches towards historical imagery. I then explore these approaches with particular reference to how the Cold War is taught in Swiss schools. Consequently, using examples from Swiss history textbooks, I demonstrate how such historical imagery manifests itself at the level of history teaching. The questions the chapter aims to answer always relate to changes in visual thinking and the symbolic potential of different images, particularly focussing on the imagery which recurs when textbooks treat the immediate post-war phase of the Cold War.

\section{Theoretical Considerations on Historical Imagery}

The term 'image' encompasses both an internal (image) as well as an external (picture) visual impression, so that both aspects are reflected in a single term (Boehm 2007, 11). This conceptual doubling illustrates how closely connected the visual imagination is to the form of expression and the perception of the physical image. It is thus mainly in the surplus of meaning which the image - painted or also only imagined - creates that it achieves its effect. Furthermore, since what is referred to as the iconic turn', scholars have also realised that knowledge becomes accessible not merely through language (Bachmann-Medick 2009, 351), but is rather shaped and produced by underlying images - a kind of visual thinking. Images actually stand for the dimension of 'showing' and are inherently strongly suggestive. Such image-active movements of thought can lead to the visual acts through which we create myths (Bachmann-Medick 2009, 352).

If imagery creates narratives, then the reverse is also true: Narratives create actual visual worlds in our imagination by providing each individual with abstract, internal historical images. These are often employed in our everyday use of language in order to refer back to memory culture and to different interpretations of historical processes. This theory focusses on 
the visual potency of language, which here becomes actual metaphorology, to use Hans Blumenberg's term (Boehm 2007, 44).

As historical images are thus always subject to trends and linked to the politics of history (Furrer 2013, 222), political debate focusses on the promises that narratives make to mobilise political forces and catalyse change. Thinking in images allows for the reduction of ambivalence in narratives, rendering superfluous fundamental justifications by reducing alternatives and thus easing decision-making (Rödder 2015, 298). Individuals interpret these images and search for meaning, even if this contradicts an accepted logic and evidence, in order to distinguish between fact and fiction (Hobsbawm 2002, 296).

Just as it is accessible through imagery in the present, the conflict was accessible for an audience in the forties through images and even image series, which both the movies and the spread of television in the fifties rendered possible. Thus, the Vietnam War became a 'living room war' (Paul 2004, 314). For the first time, mass media carried both a 'hot' proxy war and the Cold War into people's homes and, consequently, the general public in the US criticised American involvement in the conflict. The images transmitted on television were too horrible to not have some sort of effect on the ordinary individual.

\section{Switzerland during and after the Cold War}

According to Buomberger $(2017,20)$, the world was gradually slipping into the Cold War and for the Swiss people this meant an almost seamless transition from fearing National Socialism and Fascism to fearing the perceived threat of communism. The Cold War united Swiss society, creating a closed protective community which had not existed during the Second World War. The (marginal) Swiss communist party came under suspicion. Historians have argued that fierce anti-communist sentiment in Switzerland was barely less pronounced than in the McCarthyist US and that the Swiss could actually fall back on a longer tradition of anticommunism (Caillat et al. 2009). This policy lasted for the entirety of the Cold War period, even if there was a decline in the 'structure-forming' power derived from the East-West contrast (Ritzer 2015, 23). The feeling 
that war was imminent, and could ignite at any moment like a spark in a powder keg, was widespread in Switzerland. The early post-war period was in particular marked by two basic characteristics - the Swiss people's paralysing fear of the atomic bomb as well as the hope of better living conditions and a shared optimism about the progress of the country.

Historians also suggest that these hopes and fears in Switzerland were fed by the triangular relationship between consumption, the Cold War and consensus (Leimgruber 1992, 18-23). The economic boom made distribution issues and thus political consensus-building much easier. At the Swiss national exhibition, 'Expo', in Lausanne in 1964 the question as to how the country could survive in the event of a nuclear war was prominent. The exhibition suggested methods such as the 'concrete hedgehog' which demonstrated the people's readiness to defend themselves. In the entrance area, the organisers of the exhibition displayed steel plates perforated by gunfire to show the destructiveness of war, juxtaposed with the 'fortress Switzerland' which suggested safety and security. A permanent readiness to defend oneself was therefore encouraged, as the exhibition sought to demonstrate that the small state was able to survive on its own (Furrer, 250). Intellectuals during this period were aware of the image of a 'neurotic hedgehog' (Künzli 1964), and the writer Max Frisch and historian von Salis, among others, complained about the narrow-mindedness of society and its 'totalitarian tendencies' (Furrer, 249). Switzerland built bunkers and, with the Hungarian crises in 1956, fortification-enhancement in Switzerland thrived all the more. No European country possessed more artillery guns (Auf der Maur 2017, 99).

When analysing the Cold War it is important to both distinguish between 'structure-forming' dynamics and forms of expression as well as to look at their interactions. Obviously the political elite relied on the image of the Soviet Union as an enemy because it allowed them to practice a passive foreign policy in the shadow of the Western Alliance and simultaneously to pursue apparent autonomy through its domestic policy (Furrer, 249). Switzerland was a stowaway of NATO, as Joëlle Kuntz aptly puts it (2014, 14). For Jakob Tanner, the Cold War consolidated the Swiss myth of sovereignty $(2015,305)$, which resonated with the Swiss public 
and, in foreign policy terms, allowed the country to integrate itself into the Western sphere in economic (if not political) terms. Anti-communist sentiment had a strong impact in Switzerland: The bourgeois and the religious, amongst others, saw the core values of Western civilisation as endangered. The Cold War and anti-communism thus created cohesion within a country which, as historians have pointed out, struggled with severe social tensions (Buomberger 2017, 22), as the majority of people suddenly shared a similar world view, one which distanced Switzerland from the perceived threat by demonising an external and internal enemy. The East-West dualism turned out to be very adaptable, incorporating classical constructs from the modern and pre-modern age which systematically included or excluded certain groups of people (Imhof et al. 1996, 177). In Switzerland, for instance, anti-Slavism was on the rise, demonstrating how the issue of race was treated in the country, and, on an ideological level, communism was often associated with images of a Marxist antichrist. At the same time, images of freedom and folklore bolstered Swiss nationalism, fuelling exclusion of the 'other'. Such cultural codes created meaning and reinforced the effectiveness of anti-communist feeling in the country (Imhof et al. 1996, 177), turning it into a 'creed' (Buomberger 2017, 40 ff.).

Although the Cold War was not seen as a linear progression of events in Switzerland, this global conflict intensely and permanently impacted upon foreign and domestic policy: 'The Cold War created the optimum conditions for the merging of nation and state' (Furrer 1998, 110), rendering the end of the conflict all the more disruptive in this regard. Switzerland now had to fundamentally reorient its worldview (Furrer, 126) and thus confront its own history. Tanner and Weigel point out that each society views history in a way which it both deserves and can bear. History even becomes a causal factor in crisis-ridden phases of reorganisation as the interpretation of the past can either engender change or consolidate already existing structures and beliefs (Tanner and Weigel 2002, 20).

Central to this discourse was the question of whether Swiss neutrality, seen as a highly valuable state policy, should be maintained after the Cold War. It had only been temporarily rejected by the Communist Workers' Party in the first few post-war years, and all political camps considered it 
useful when making foreign policy decisions. Essentially, the Cold War shaped Switzerland's self-conception as a country in which neutrality was highly (perhaps excessively) valued. The East-West divide led to a higher value being placed on the role and function of neutral states, services certainly employed by the Soviet Union, amongst others. In Switzerland, neutrality was never associated with a neutrality of political conviction but rather with a maxim of state foreign policy. It is not, therefore, surprising that by the end of this global conflict questions as to the future political orientation of the country, including the issue of neutrality, were being raised.

Soon two camps had emerged: For one side the fixation on neutrality blocked future foreign policy actions, adding to an already negative image of an isolated, self-interested and introverted small state. Critics attacked Swiss 'neutral morality' during the Cold War (Furrer, 119f.), especially political abstinence and, at the same time, its intensive economic integration (Furrer, 126). Fearing that such a stance would prevent the development of an open-minded country, this group demanded nothing less than a redefinition of neutrality (Kreis 2004, 367-368). However, some argued that the value of neutrality as a strategy had been proven during the Cold War: Switzerland's exceptional position rendered it both capable of and also a beneficiary of a neutral stance, as a small state thus able to make full use of its sovereignty. In the context of the debate about Switzerland's position towards Europe (and the European Union) and the world (e.g., towards the UN, of which Switzerland became a member in 2002), this dispute over the value of neutrality was virulent. However, with new international and European crises from 2008 onwards the vehemence of the dispute has decreased.

\section{Historical Imagery in Swiss History Textbooks}

History textbooks that have been reprinted in new editions or published for the first time since the end of the Cold War were thus presented with the essential challenge of how to present this conflict. Significant differences become apparent when comparing them with books from the Cold War era: The latter mostly relied on a traditional interpretation of 
the Cold War, with imagery of a threatening Eastern superpower with its military machine. Arguments put forward in these textbooks were based on competing narratives about systems and ideologies, entirely in regards to ideas of progress. As a so-called 'neutral' state, Switzerland is generally not directly included in these narratives. The Cold War was thus considered an external event (Furrer 2016, 285). An exception occurs in the context of events between 1989 and 1991 - and only then in new narratives. These narratives are equally underpinned by pictorial thinking, for which there are a number of reasons: On the one hand, they have only limited space available for their depictions of the past, not always sufficient for an accurate historical analysis. On the other, the selection of content about the past takes place from the perspective of the present, charging these contents with the 'now' in the sense described by Walter Benjamin. In history didactics, the term 'orientation towards the present' is widely used for this purpose, in this context primarily in the sense of 'context of meaning' (Pandel 2013, 333).

This analysis focuses on representations of Switzerland during the Cold War. While textbooks from the Cold War period hardly ever directly associate Switzerland with the conflict, since the end of the bipolar divide it has increasingly been portrayed as a country with a society that was also involved. Until the end of the Cold War, Switzerland appeared as a country practically untouched by the 'Age of Catastrophe' (Hobsbawm 1994, 21 ), in a position to contemplate the world and Europe from the 'balcon sur l'Europe' (Pierre Béguin). For students in school, this had the peculiar effect that history generally took place outside the country (Furrer et al. 2008, 11). It was not until new history textbooks came out in the 1990s that Switzerland and its society were linked to the Cold War, primarily via anti-communism, which at the time was widespread and vehement in Switzerland. Yet here too we find exceptions to the rule: Histoire générale contains no reference to Switzerland at all over some 20 pages on the Cold War (Histoire Générale 1999, 964-984). The end of ideological antagonism brought with it a self-critical glance back at mechanisms of exclusion, defamation and setbacks within society, images of anticommunist propaganda being among the most prominent. There are, however, also other pictorial references. Why is it specifically images we are examining here? Why and how do textbooks in particular convey 
these? In many cases, complex historical facts are 'reduced', conveyed in a simple and mono-causal, yet highly memorable, fashion. Examining the pictorial character of these references illustrates how such portrayals are both highly selective and also target-group orientated, of only limited analytical value since the thought processes employed by historical research are barely recognisable. Images, as such, are highly conducive to the eclectic nature of many textbook portrayals. As Hans-Jürgen Pandel has put it, textbook texts tend to be enumerative rather than narrative (Pandel 2005, 37), and new teaching materials in particular tend to thus convey a selection of brief impressions of history.

If we analyse textbooks published between the 1990s and the present day, we are seeking, via images, fundamental interpretations underlying narratives on Switzerland in the Cold War. Four particular references link Switzerland and its society to the conflict: first, the image of anticommunist and hysterical Switzerland mentioned above, to be found in almost all teaching materials currently available. Threatening images also involve Switzerland in international conflicts, particularly via a widespread triangular constellation of Switzerland and its society caught between economic boom, concordance democracy and the Cold War is particularly widespread. The image of the division and reunification of the continent, including Switzerland, is also used. While, at first glance, these images appear to have been selected at random, they are underpinned by time-bound discourses that guide the textbooks.

\section{The Image of 'Hysterical Switzerland'}

The textbook Die Schweiz und ihre Geschichte (Switzerland and its History), designed as supplementary material for upper secondary level, deals with 'The Cold War in Switzerland?' (note the question mark). A page and a half long, the section traces the inner-societal mood, characterised by a mentality of seclusion and distance: 'Switzerland came across as a spectator at a football match, fully committed to the team from the stands, but under no circumstances willing to enter the playing field' (Die Schweiz und ibre Geschichte 2005, 170 , all textbook translations by the author). This simile contains two 
essential aspects: the neutral attitude towards the outside world and the anti-communism within Switzerland, directed particularly against the Soviet-friendly Swiss 'Partei der Arbeit' (=Communist Party), and - according to critical contemporaries of the time (Jean Rudolf von Salis) was taking on ,hysterical proportions'. The texts are supplemented by two images, a portrait of a Swiss communist, Edgar Woog (1898-1973), who described himself as a 'proud Muscovite', and a campaign placard of black rats nibbling on the white Swiss cross against a red background. The latter is from the mid-1960s, and was carried by the 'campaign against trade with the East'. 'The textbook Menschen in Zeit und Raum (People through Time and Space) another example, dedicates a double page to the topic of Switzerland in the Cold War: the 'Cold War within the Country' is portrayed using the example of the 1956 Hungarian Uprising, which led to a large movement in Switzerland calling for solidarity with the insurgents and the refugees, yet also to anti-communist sentiment. One photograph, for instance, shows refugees dangerously crossing a small river marking the boundary between Hungary and Austria. Another photograph depicts a vigil held in Berne after the suppression of the uprising, demonstrating and lighting candles in solidarity (Menschen in Zeit und Raum 2005, 128-129). This strong involvement of Switzerland in the Cold War via anti-communism can be found today in almost all textbooks, including Gesellschaften im Wandel (Societies in Transition). The Cold War created a 'climate of fear' $(2017,102 / 03)$.

These references can be explained particularly well by the discourses and developments in Switzerland after the Cold War. The end of the conflict brought about a 'Jahrhundertskandal' (scandal of the century), when it became apparent in 1990 that the federal police had been registering anything that appeared 'un-Swiss' for fear of subversive tendencies. Some 900000 people and organisations had been subject to surveillance. Intellectuals, such as the writer Max Frisch, who were themselves affected, wrote of a 'state gone bad' and dramatist and painter Friedrich Dürrenmatt coined the image of 'Switzerland as a prison in which the prisoners were also the guards. It was perhaps this scandal that opened the people's eyes to the arbitrary nature of the surveillance and also the problematic nature of the anti-communist obsession (Tanner 
2015, 471). Anti-communism thus becomes a metanarrative for Switzerland in the Cold War. The textbook Gesellschaften im Wandel features a colour photograph of a 1990 demonstration in Berne against 'snooping Switzerland' (Schnüffelstaat) with protesters carrying a banner with the slogan: 'Sniff around at your own arses' (schnüffeln = spy/ snoop/sniff, Gesellschaften im Wandel 2017, 103).

\section{The Nuclear Threat: A Paradoxical Image}

Another memorable image derives from the perception of a specific threat from the 1980s. In Weltgeschichte im Bild (World History in Pictures, 1990, 54-65), the idea of nuclear threat and imminent war is predominant and conveyed through imagery and photographs. In the chapter Welt zwischen Ost und West (The World between East and West), the topic is introduced by a quote from Arthur Koestler's book of 1978, Janus: A Summing Up: 'Since the day when the first atomic bomb outshone the sun over Hiroshima, mankind as a whole has had to live with the prospect of its extinction as a species'. (Weltgeschichte im Bild 1990, 54). The events then mentioned in the textbook all follow on from the presentation of this particular threat. One of the pictures shows an American missile silo; in another we can see the building site for launching pads in Cuba, photographed by reconnaissance aircrafts (Weltgeschichte im Bild 1990, 56 and 58). The Vietnam War is directly connected with the Cold War in this textbook, which focusses on the 'face of the war' as it also uses photography (Weltgeschichte im Bild 1990, 69). In the final chapter on the topic, explanations of the peace movement and 'peace as a goal' follow with an excursus on the law of nations. The textbook refers to the peace movement which gained strength in Switzerland in the 1980s, although it never found the same resonance as it did in the Federal Republic of Germany, against the background of the NATO Double-Track Decision, which triggered new arms dynamics and discussions. However, the textbook consistently focusses on the perceived threat to Switzerland, as well as emphasising proposed solutions to the conflict, such as the peace movement. This textbook is the only one with such a succinct approach to this area of focus. Other textbooks published between 1990 and 2000 hardly mention the nuclear threat at all 
(e.g. Menschen in Zeit und Raum 2005, 116-131). It is striking how casually images of threatening scenarios are presented in other textbooks (e.g. Histoire générale 1994, Weltgeschichte 1993). This is particularly true of material on the Cold War, which generally ignores the threat of war against Switzerland. Alternatively, a kind of controllability is suggested, such as via the image of the American SDI Program (Strategic Defense Initiative), which illustrates how 'attacking intercontinental missiles' can be intercepted and safely destroyed using space satellites (Weltgeschichte 1993, 290). Although the current textbook Gesellschaften im Wandel $(2017,99)$ does refer in more detail to the threat posed by nuclear weapons, the threat itself remains an abstract one. A colour photograph shows the mushroom cloud over Nagasaki; however, there is no discussion of the dangers to which humankind was exposed.

While this can be explained, it is also paradoxical. While only a few years after the end of the bipolar conflict the feeling of an immediate nuclear threat was on the wane, it is paradoxical that, even during the Cold War, despite a widespread perception of the threat, it is rarely addressed in teaching materials. On the contrary, a nuclear clash is even considered non-life threatening thanks to the Swiss army and civil defence. In the midst of the Cold War, this was a message of serenity and assurance, also conveyed in the form of images, as in the voluminous popular science work by Peter Dürrenmat, which presents a full-page black and white photograph of four fighter jets flying in formation in front of a Swiss Alpine backdrop (Schweizer Geschichte 1963, 705). The paradoxical way in which fear was addressed only became of interest to historiography at a later stage. Thomas Buomberger recalls a society in the hedgehog position, sheltered in underground civil defence bunkers, ready to defend itself and prepared for emergencies, indignant for and helpful towards the Hungarian rebels and refugees, but also at the mercy of a hysterical surveillance state (Buomberger, 2017). Buomberger thus presents visual worlds from the perspective of the present which had, in fact, already been shaped by imagery from the period. For example, the public were exposed to contemporary photographs of the abovementioned 'concrete hedgehog' at the Expo in Lausanne, of the defence minister in a military aircraft (showing the readiness of the small state for war) and the Swiss population organising aid packages for the insurgents 
in Hungary in 1956. Others showed protest marches against trade with the East after the construction of the Berlin Wall in 1961, the defence shelters and, at the end of the Cold War in 1989/90, the demonstrations against state surveillance (the latter also targeted the army, which some wished to slaughter symbolically as a 'holy cow').

\section{Switzerland in the Cold War between Boom and Concordance Democracy}

No other Swiss textbook for lower secondary school is so strongly devoted to the subject of the Cold War, which runs as a guiding theme through the entire fourth volume of Durch Geschichte zur Gegenwart (1991). This book (To the Present via the Past) explains world affairs and the history of Switzerland, and provides interesting insights as to how Switzerland is embedded within the Cold War context, bringing together internal and external perceptions. The Cold War era is directly associated with the 'Swiss economic miracle' and the continued development of Swiss consensus and the concordance system, which in 1959 led to an all-party government that remained in its original constellation until 2003 (Durch Geschichte zur Gegenwart 1991, 69-73). This connection between the Cold War and the concordance system is also made by other textbooks. While it is a widespread idea, it has a highly associative effect, particularly where only few areas of overlap are apparent. In the Swiss history textbook Schweizer Geschichte (History of Switzerland, 2008, 94-98), the Cold War is presented within a Swiss context using a double-page black and white photograph of demonstrators from 1956, pushing forwards in front of the Soviet embassy in Berne, monitored and held back by Swiss law enforcement in 1950s uniforms. The image conveyed is one of an active anti-communist Swiss population protesting during the Cold War and calling for the expulsion of the Russians from Hungary: 'Down with the USSR!' (Schweizer Geschichte 2008, 94). This depiction is then followed in the textbook by mention of the Swiss concordance system. The Cold War thus becomes a kind of 'sub-chapter' of 'The Concordance System' (Schweizer Geschichte 2008, 96). The textbooks thus suggest a triangular association between 'concordance, consumerism and the Cold 
War', very much in line with the vivid formula given prominence at the end of the conflict in the context of a 'special case' as presented in anniversary publications and exhibitions: a Switzerland between Réduit (the Swiss term for the National Redoubt, Alpine fortifications put in place during the Second World War) and Europe (see Leimgruber 1992, 23).

\section{The Image of Division and Reunification of the Continent}

The textbook Menschen in Zeit und Raum dedicates several pages to the Cold War, presented as Welten im Kalten Krieg (Worlds in the Cold War, Menschen in Zeit und Raum 2005, 108-133). The narrative is no longer one of competition but instead one of separation (Furrer 216, 287), which allows for two kinds of pictorial representation. On the inside front cover of this textbook, a family contemplates the remains of the Berlin wall (Menschen in Zeit und Raum 2005, 108/09). The idea of separation, 'An iron curtain falls' (Menschen in Zeit und Raum 2005, 117), recurs through imagery, becoming a major theme and means of interpretation in the narrative.

The image of a now-reunified Europe, divided after the Second World War, also embodies a meta-narrative for the Cold War in this textbook. Switzerland is also indirectly involved: solidarity with the Hungarians during the 1956 uprising is discussed in relation to Switzerland, and 'everyday life in Communist Hungary' is documented over a double page (Menschen in Zeit und Raum 2005, 120/21). The textbook Gesellschaften im $\operatorname{Wandel}(2017,100 / 01)$ features two fictional stories about young people in East and West Berlin, who in an interview describe the everyday lives of young people in the two systems with the theme 'Two Worlds One Friendship'. The image materials used all show the East: people queuing for bananas in front of a grocery store in 1985, and boys from the Freie Deutsche Jugend organisation, in action cleaning a water ditch. The division and reunification were highly significant European events, with direct relevance for the metaphor of the 'European house', given current status in the second half of the 1980s through the politics and rhetoric of Soviet party Secretary-General Mikhail Gorbachov (Kreis 2012, 577). 
History textbooks mostly pick up on historico-cultural interpretations directly. Retrospective points of view of the Cold War are incorporated into their narratives and offer different methods of interpreting history. Since looking at history inevitably means connecting the past with the challenges of the future (Jeismann 2008, 34), these views find their way into textbooks and even popular science.

\section{Conclusion}

Overall, it becomes apparent that the Cold War, to use the discourse of memory culture, is both remembered and perceived on the basis of visual thinking. This is particularly the case when references to the present are made. The Cold War is an epoch which survives in the deep structures of current political and social life (Greiner 2013, 9). It is precisely because the Cold War now has such a strong effect on the present that it continues to be intensely remembered and thus achieves a specific significance in memory culture, one that - as demonstrated in this chapter - is firmly informed by visual thinking. While such image-based conceptions may tend to be judgmental and emotive, they are also highly selective and lack analytical potential (Furrer 2013, 222), rather serving to provide simple arguments.

The image-based approaches have taken the example of current Swiss history textbooks portraying Switzerland during the Cold War era. If we analyse textbooks from this period, it becomes clear how Switzerland can be woven into international events with only a few points of contact: the anti-communist hysteria and the idea of a country caught between consumption, consensus and the Cold War. Both these images are widely used, in almost all textbooks from the 1990s. Conceptions of threat also feature in retrospective portrayals, as does the image of the divided and after 1989 - reunified continent. While these images are to be found in specific textbooks, all textbooks have clearly grown from current discourses and challenges. They offer highly selective portrayals with which to grasp and interpret the complex events of the Cold War era.

History teaching is faced with challenges in dealing with such a societally as well as politically loaded era of contemporary history. As the 
references to visual thinking exemplify, clear tendencies can be recognised in society and politics but also in teaching 'lessons' from history, raising the 'moral index finger'. Yet rarely do these authors point out how the past continues to impact the present, or highlight the potential of historical events, a deficit related to the function and use of history in society. The British-Australian historian Christopher Clark said in an interview that history was no schoolmaster but rather resembled the Oracle of Delphi. Indeed, image conceptions do appear to resemble an oracle, particularly in relation to the Cold War, a period remembered primarily in pictorial terms. As history now provides the only learning material at our disposal, it is important to ensure that not only educated elites have access to this knowledge by deconstructing the flood of images, analysing them as history with a specific purpose, and at the same time remaining aware of the complex structures of historical processes.

\section{Notes}

1. The term 'Cold War' had already been used by George Orwell in an essay of 1945 to describe the confrontation of the superpowers. The journalist Herbert Swope introduced the term in a speech he wrote for the American political advisor Bernard Baruch in 1947. The term was then popularised by the American journalist Walter Lippmann.

2. The Swiss Reconnaissance Service (Schweizerische Aufklärungsdienst, SAD) was founded in Zurich in 1947 when the onset of the Cold War appeared imminent. It became the most important organisation of the anti-communist Geistige Landesverteidigung (Spiritual National Defence). The activities of the SAD reached their peak at the beginning of the 1960s with campaigns against trade with the East as well as sport-related and cultural activities with communist states.

\section{Bibliography}

\section{List of Textbooks Cited}

Weltgeschichte: Vom Wiener Kongress bis zur Gegenwart. 1993. Vol. 2. J. Boesch and R. Schläpfer. Zurich: Orell Füssli. 
Histoire Générale: L'époque contemporaine 1914-1990. 1999. Vol. 5. C. Bourgeois.

Lausanne: Département de la Formation et de la Jeunesse du canton de Vaud. Histoire Générale de 1919 à nos jours. 1994. G.-A. Chevallaz. Lausanne: Editions Payot.

Schweizer Geschichte. 1963. P. Dürrenmatt. Zurich: Druck- und Verlagshaus AG.

Gesellschaften im Wandel: Themenbuch 1 und 2. 2017. Zurich: Lehrmittelverlag Zurich.

Menschen in Zeit und Raum: Viele Wege - eine Welt. Erster Weltkrieg bis Globalisierung 9. 2005. Buchs: Lehrmittelverlag des Kantons Aargau.

Durch Geschichte zur Gegenwart. 1991. Vol. 4. H. Meyer and P. Schneebeli. Zurich: Lehrmittelverlag des Kantons Zürich.

Die Schweiz und ihre Geschichte: Vom Ancien Régime bis zur Gegenwart. 2005.

H. Meyer, P. Felder Pierre and J.C. Wacker. Zurich: Lehrmittelverlag des Kantons Zürich.

Schweizer Geschichte 4: Zeitgeschichte seit 1945. 2008. Th. Notz et al. Berlin: Cornelsen.

Weltgeschichte im Bild 9. Buchs: Lehrmittelverlag des Kantons Aargau, 1990.

\section{Further References}

Albrecht, Peter, Andreas Gross, August E. Hohler, Peter Hug, Wolfgang Lauterburg, Thomas Schnyder, Monika Stocker-Meier, Jürg Stöcklin, Joachim Suchomski and Jakob Tanner. 1988. Schutzraum Schweiz. Mit dem Zivilschutz zur Notstandsgesellschaft. Berne: Zytglogge.

Auf der Maur, Jost. 2017. Die Schweiz unter Tag. Eine Entdeckungsreise. Basel: Echtzeit.

Bachmann-Medick, Doris. 2009. Cultural Turns. Neuorientierungen in den Kulturwissenschaften. Reinbek bei Hamburg: Rowohlt.

Benjamin, Walter. 1980. Gesammelte Schriften, Vol. 1-2. Frankfurt/Main: Suhrkamp.

Boehm, Gottfried. 2007. Wie Bilder Sinn erzeugen. Die Macht des Zeigens. Berlin: Berlin University Press.

Buchbinder, Sascha. 2002. Der Wille zur Geschichte. Schweizergeschichte um 1900 - die Werke von Wilhelm Oechsli, Johannes Dierauer und Karl Dändliker. Zurich: Chronos.

Buomberger, Thomas. 2017. Die Schweiz im Kalten Krieg 1945-1990. Baden:

Hier und Jetzt. 
Caillat, Michel, Mauro Cerutti, Jean-François Fayet and Stéphanie Roulin, eds. 2009. Geschichte(n) des Antikommunismus in der Schweiz. Zurich: Chronos.

Furrer, Markus. 2017. 'A View of the Cold War in the Swiss Historical Narrative'. In Remembering and Recounting the Cold War - Commonly Shared History?, edited by Markus Furrer and Peter Gautschi, 111-128. Schwalbach/Ts.: Wochenschau Verlag.

Furrer, Markus. 2016. 'Gebrochene Geschichten des Kalten Krieges - Narrative und der Umbruch 1989-91 in Schweizer Geschichtslehrmitteln'. In 1989 und Bildungsmedien. Beiträge zur historischen und systematischen Schulbuchund Bildungsmedienforschung, edited by Eva Matthes and Sylvia Schütze, 278-287. Bad Heilbrunn: Verlag Julius Klinkhardt.

Furrer, Markus. 2013. 'Geschichtsbilder in Migrationsgesellschaften'. In Antike - Bilder - Welt. Forschungserträge internationaler Vernetzung. Elisabeth Erdmann zum 70, edited by Charlotte Bühl-Gramer, Wolfgang Hasberg and Susanne Popp, 217-232. Schwalbach/Ts.: Wochenschau Verlag.

Furrer, Markus, Kurt Messmer, Bruno H. Weder and Béatrice Ziegler. 2008. Die Schweiz im kurzen 20. Jahrhundert. 1914 bis 1989 - mit Blick auf die Gegenwart. Zurich: Verlag Pestalozzianum.

Furrer, Markus. 2004. Die Nation im Schulbuch - zwischen Überhöhung und Verdrängung. Leitbilder der Schweizer Nationalgeschichte in Schweizer Geschichtslehrmitteln der Nachkriegszeit und Gegenwart. Hanover: Verlag Hahnsche Buchhandlung.

Furrer, Markus. 1998. 'Die Apotheose der Nation. Konkordanz und Konsens in den 1950er Jahren'. In Die Konstruktion einer Nation. Nation und Nationalisierung in der Schweiz, 18.-20. Jahrhundert, edited by Urs Altermatt, Catherine Bosshart-Pfluger and Albert Tanner. Zurich: Chronos.

Greiner, Bernd. 2013. Spurensuche: Zum Erbe des Kalten Krieges. In Erbe des Kalten Krieges, edited by Bernd Greiner, Tim B. Müller, Klaas Voss. 9-41. Hamburg: Verlag des Hamburger Instituts für Sozialforschung.

Hobsbawm, Eric. 1994. The Age of Extremes: A History of the World, 1914-1991. London: Michael Joseph and Pelham Books.

Hobsbawm, Eric. 2002. Interesting Times: A Twentieth-Century Life. London: The Penguin Press.

Imhof, Kurt, Heinz Kleger and Gaetano Romano, eds. 1996. Wiedergeburt der geistigen Landesverteidigung: Kalter Krieg in der Schweiz. Konkordanz und Kalter Krieg. Analyse von Medienereignissen in der Schweiz der Zwischen- und Nachkriegszeit. 173-247. Zurich: Seismo. 
Jeismann, Karl-Ernst. 2008. 'Geschichtsbilder: Zeitdeutung und Zukunftsperspektive'. In: Dossier Geschichte und Erinnerung. Berlin: Bundeszentrale für politische Bildung, 34-47. http://www.bpb.de/geschichte/ zeitgeschichte/geschichte-und-erinnerung/ (last accessed 9 February 2016).

Kreis, Georg. 2004. Kleine Neutralitätsgeschichte der Gegenwart. Ein Inventar zum neutralitätspolitischen Diskurs in der Schweiz seit 1943. Berne/Stuttgart/ Vienna: Haupt Verlag.

Kreis, Georg. 2012. 'Das Europäische Haus'. In Europäische Erinnerungsorte 2, edited by Pim den Boer, Heinz Duchhardt, Georg Kreis and Wolfgang Schmale, 577-584. Munich: Oldenbourg Verlag.

Kuntz, Joëlle. 2014. Die Schweiz-oder die Kunst der Abhängigkeit. Zwischenruf, Zurich: Verlag Neue Zürcher Zeitung.

Künzli, Arnold. 1964. 'Die Neurose des Igels'. In Expo 64: Trugbild der Schweiz, edited by Walter Biel et al. 35-49. Basel: Basilius Presse.

Leimgruber, Walter. 1992. 'Die Schweiz zwischen Isolation und Integration'. In Sonderfall? Die Schweiz zwischen Réduit und Europa, edited by Walter Leimgruber and Gabriela Christen, 18-33. Zurich: Schweizerisches Landesmuseum.

Pandel, Hans-Jürgen. 2005. Geschichtsunterricht nach Pisa. Kompetenzen, Bildungsstandards und Kerncurricula. Schwalbach/Ts: Wochenschau Verlag.

Pandel, Hans-Jürgen. 2013. Geschichtsdidaktik. Eine Theorie für die Praxis. Schwalbach/Ts: Wochenschau Verlag.

Paul, Gerhard. 2004. Bilder des Krieges - Krieg der Bilder. Die Visualisierung des modernen Krieges. Zurich: Verlag Neue Zürcher Zeitung.

Ritzer, Nadine. 2015. Der Kalte Krieg in den Schweizer Schulen. Berne: hep Verlag.

Rödder, Andreas. 2015. 21.0. Eine kurze Geschichte der Gegenwart. Munich: C.H. Beck.

Rüsen, Jörn. 2008. Historische Orientierung. Über die Arbeit des Geschichtsbewusstseins, sich in der Zeit zurechtzufinden. Schwalbach/Ts.: Wochenschau Verlag.

Stöver, Bernd. 2007. Der Kalte Krieg. Geschichte eines radikalen Zeitalters 1947-1991. Munich: C.H. Beck.

Tanner, Jakob. 1988. 'Totale Verteidigung im bedrohten Kleinstaat. Vom Luftschutz der Zwischenkriegszeit bis zur Zivilschutz-Konzeption 1971’. In Schutzraum Schweiz. Mit dem Zivilschutz zur Notstandsgesellschaft, edited by Peter Albrecht et al., 59-109. Berne: Zytglogge. 
Tanner, Jakob. 2015. Geschichte der Schweiz im 20. Jahrhundert. Munich: C.H. Beck.

Tanner, Jakob and Sigrid Weigel. 2002. 'Gedächtnis, Geld und Gesetz in der Politik mit der Vergangenheit des Zweiten Weltkriegs und des Holocaust'. In Gedächtnis, Geld und Gesetz. Vom Umgang mit der Vergangenheit des Zweiten Weltkrieges, edited by Jakob Tanner and Sigrid Weigel, 7-18. Zurich: vdf Hochschulverlag an der ETH Zürich.

Weigel, Sigrid. 1997. Entstellte Ähnlichkeit. Walter Benjamins theoretische Schreibweise. Frankfurt/Main: Fischer.

Open Access This chapter is licensed under the terms of the Creative Commons Attribution 4.0 International License (http://creativecommons.org/licenses/ by/4.0/), which permits use, sharing, adaptation, distribution and reproduction in any medium or format, as long as you give appropriate credit to the original author(s) and the source, provide a link to the Creative Commons licence and indicate if changes were made.

The images or other third party material in this chapter are included in the chapter's Creative Commons licence, unless indicated otherwise in a credit line to the material. If material is not included in the chapter's Creative Commons licence and your intended use is not permitted by statutory regulation or exceeds the permitted use, you will need to obtain permission directly from the copyright holder.

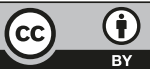

